\title{
Keanekaragaman dan komposisi kumbang elaterid (Coleoptera: Elateridae) di kawasan hutan hujan tropis Taman Nasional Bukit Duabelas dan Hutan Harapan, Jambi
}

\author{
Diversity and species composition of elaterid beetles \\ (Coleoptera: Elateridae) in tropical rainforests in \\ Bukit Duabelas National Park and Hutan Harapan, Jambi \\ Kasmiatun $^{1}{ }^{*}$, Rizky Nazarreta ${ }^{1}$, Damayanti Buchori ${ }^{1,2}$ \\ ${ }^{1}$ Departemen Proteksi Tanaman, Fakultas Pertanian, Institut Pertanian Bogor \\ Jalan Kamper, Kampus IPB Dramaga, Bogor, Jawa Barat 16680 \\ ${ }^{2}$ Center for Transdisciplinary and Sustainability Sciences (CTSS), IPB University \\ Jalan Raya Pajajaran No. 27, Bogor 16128 \\ (diterima Agustus 2019, disetujui Februari 2020)
}

\begin{abstract}
ABSTRAK
Provinsi Jambi merupakan salah satu daerah di Indonesia yang memiliki hutan hujan tropis dengan karakteristik lanskap berbeda di setiap wilayah. Beragam jenis flora dan fauna dapat ditemukan di kawasan hutan hujan tropis ini, di antaranya kumbang elaterid. Kumbang elaterid diketahui berperan penting sebagai bioindikator dalam penelitian ekologi. Penelitian ini bertujuan untuk memelajari pengaruh perbedaan lanskap terhadap keanekaragaman dan komposisi kumbang elaterid. Pengambilan sampel dilakukan di daerah Jambi pada dua lanskap hutan hujan tropis, yaitu lanskap Taman Nasional Bukit Duabelas (TNBD) dan Hutan Harapan. Kumbang elaterid dikumpulkan melalui metode pengasapan (fogging) yang dilakukan pada pagi hari. Pada setiap lanskap ditentukan 4 plot dan pada masing-masing plot terdiri atas 3 subplot sehingga total subplot yang diamati di kedua lanskap sebanyak 24 subplot. Total kumbang elaterid yang terkoleksi sebanyak 2.069 individu, terdiri atas 6 subfamili, 23 genus, dan 59 morfospesies. Jumlah individu tertinggi ditemukan pada lanskap Hutan Harapan, sedangkan jumlah morfospesies tertinggi ditemukan pada lanskap TNBD. Kumbang elaterid yang mendominasi kedua lanskap terdiri atas Subfamili Agrypninae dengan Genus Adelocera dan morfospesies Adelocera sp.01. Hasil analisis menunjukkan bahwa perbedaan lanskap memengaruhi komposisi dan kelimpahan individu kumbang elaterid, akan tetapi tidak memengaruhi kekayaan spesies kumbang elaterid.
\end{abstract}

Kata kunci: kekayaan spesies, kelimpahan individu, lanskap

\begin{abstract}
Jambi province is one of the regions in Indonesia that has tropical rainforests with different landscape characteristics in each region. Tropical rainforests contain the highest biodiversity in the world and as a habitat for various types of flora and fauna, including elaterid beetles. Elaterid beetles have an important role as ecological bioindicators. The aim of this research was to study the diversity and species composition of elaterid beetle in two different landscape types. Insect sampling was carried out in Jambi Province on two tropical rainforest landscape, i.e. Bukit Duabelas National Park (TNBD) and Harapan Rainforest. Elaterid beetles were collected by canopy fogging method in the morning. Each landscape consists of four core plots and each core plot consist of three as subplot, total subplots observed in both landscape were 24 subplots. A total of 2069 individuals of elaterid beetles were collected, belonging to 6 subfamilies, 23 genera, and 59 morphospecies. The abundance of elaterid beetles was higher in Harapan Rainforest, while species richness was higher in TNBD landscape. Species dominant in two landscape consist to subfamily Agrypninae, belonging to genera Adelocera with morphospecies Adelocera sp.01.
\end{abstract}

*Penulis korespondensi: Kasmiatun. Departemen Proteksi Tanaman, Fakultas Pertanian, Institut Pertanian Bogor

Jalan Kamper, Kampus IPB Dramaga, Bogor, Jawa Barat 16680. Tel: 0251-8629364, Fax: 0251-8629362, Email: kasmiatun15@gmail.com 
The result of this research showed that landscape differences influencing the composition and abundance of elaterid beetles, but it does not influence in species richness of elaterid beetles.

Key words: abundance, landscape, species richness

\section{PENDAHULUAN}

Indonesia dikenal sebagai mega diversity country karena memiliki kekayaan dan kelimpahan biodiversitas yang tinggi (Paknia et al. 2015). Selain itu, wilayah Indonesia juga diketahui sebagai salah satu negara yang memiliki hutan hujan tropis terbesar di kawasan Asia Tenggara, selain Malaysia dan Thailand (Portal Informasi Indonesia 2018). Berdasarkan data FWI (2014) dari tahun 2009 sampai dengan tahun 2013, sebesar 82 juta hektar atau sekitar $46 \%$ dari luas daratan Indonesia masih tertutupi oleh hutan. Hutan hujan tropis merupakan kawasan dengan tingkat keanekaragaman hayati tertinggi di dunia. Berbagai jenis flora dan fauna hidup di kawasan tersebut, sebagian besar spesies di dalamnya langka dan terlokalisasi (Jaboury \& Sheil 2010). Provinsi Jambi merupakan salah satu wilayah di Indonesia yang memiliki kawasan hutan hujan tropis dataran rendah, di antaranya terdapat di Taman Nasional Bukit Duabelas (TNBD) dan Hutan Harapan.

Taman Nasional Bukit Duabelas merupakan kawasan hutan lindung dengan tipe ekosistem hutan hujan dataran rendah. Kawasan ini memiliki keanekaragaman hayati yang sangat tinggi, hampir sebagian besar spesies tumbuhan dan satwa liar yang terdapat di Sumatera dapat ditemukan di kawasan ini (DEPHUT 2005). Hutan Harapan merupakan areal restorasi pertama hutan hujan tropis dataran rendah di Indonesia. Kawasan ini memiliki keanekaragaman spesies yang tinggi, akan tetapi terus mengalami penyusutan akibat perambahan dan penebangan hutan secara ilegal selama 20-30 tahun terakhir (Harrison \& Swinfield 2015). Kawasan hutan yang saat ini direstorasi merupakan campuran hutan sekunder yang masih baik dengan area yang terdegradasi. Data dari tahun 2004 sampai 2009 menunjukkan bahwa sekitar $20 \%$ dari area konsesi telah dikonversi secara illegal menjadi perkebunan kelapa sawit (Harrison \& Swinfield 2015). Hal tersebut menyebabkan terjadinya penyusutan lahan hutan dan perubahan struktur lanskap (Harrison \& Swinfield 2015).
Ordo Coleoptera merupakan bagian dari kelompok serangga yang memiliki keanekaragaman dan kelimpahan tinggi serta berperan penting pada ekosistem (Schowalter 2011). Kumbang dapat berperan sebagai pemakan tumbuhan (herbivor), pemangsa (predator), pemakan zat-zat organik yang membusuk, pemakan jamur, dan sedikit spesies bersifat parasit (Borror et al. 1996). Kumbang juga menjadi salah satu sumber makanan bagi organisme lain (Janzen 1987), berperan penting dalam proses dekomposisi siklus hara pada ekosistem hutan (Grove 2002), diketahui dapat berperan sebagai perombak kayu mati di dalam hutan, perombak hewan mati dan kotoran ternak (Kahono \& Amir 2003), serta sebagai indikator perubahan lingkungan (Warriner et al. 2002).

Salah satu famili terbesar dalam Ordo Coleoptera terdiri atas kumbang elaterid dengan lebih dari 10.000 spesies tersebar di seluruh dunia (Bouchard et al. 2017). Kumbang elaterid termasuk dalam Superfamili Elateroidea dan kumbang ini dapat menjadi salah satu bioindikator dalam penelitian evolusi dan ekologi karena memiliki sejarah habitat dan kebiasaan makan yang beragam (Kundrata 2014). Kumbang elaterid banyak ditemukan di kawasan hutan, padang rumput, semak belukar, dan berbagai habitat dengan tipe vegetasi basah maupun kering (Johnson 2002). Kumbang elaterid dikenal sebagai hama pertanian, akan tetapi beberapa spesies kumbang elaterid hidup di hutan tanpa menyebabkan kerusakan serius pada pepohonan atau tumbuhan sekitar (Thomas 2007).

Beberapa hasil penelitian menyatakan bahwa kumbang elaterid dapat berperan sebagai mangsa untuk beberapa jenis biota hutan, seperti burung (Mwansat et al. 2015), dapat berperan sebagai predator hama hutan (Morris 1951), dan sebagai mediator siklus nutrisi (Wolters 1989). Selain itu, kumbang elaterid juga berperan sebagai penyerbuk (Peter \& Johnson 2005), pemakan jamur (fungivor) (Luterek 1996), dan beberapa spesies kumbang elaterid pada fase larva bersifat saprofag (Calder 1996). Kumbang elaterid predator umumnya 
berada pada fase larva dan banyak ditemukan di antara serasah daun, di bawah kulit kayu, dan di dalam kayu yang membusuk (Johnson \& Chaboo 2015). Beberapa spesies yang tinggal di tanah dan di antara perakaran tanaman (Agriotes, Limonius, Melanotus, dan Selatosomus) merupakan hama pada biji kecambah, bibit rumput, umbi, dan sayuran (Johnson 2002).

Informasi terkait keanekaragaman kumbang elaterid di kawasan hutan hujan tropis Taman Nasional Bukit Duabelas (TNBD) dan Hutan Harapan Jambi masih sangat terbatas. Sementara itu, pengetahuan tentang kumbang elaterid menjadi salah satu informasi penting. Informasi mengenai kelimpahan, kekayaan, keanekaragaman, serta komposisi spesies kumbang elaterid dapat menjadi salah satu acuan dalam pengelolaan kawasan hutan yang mendukung ekosistem dan keberlangsungan hidup biota di dalamnya. Oleh karena itu, penelitian ini bertujuan untuk membandingkan keanekaragaman dan komposisi kumbang elaterid pada lanskap TNBD dan Hutan Harapan, Jambi.

\section{BAHAN DAN METODE}

\section{Lokasi penelitian}

Penelitian dilakukan pada dua lanskap hutan hujan tropis Jambi, yaitu di Taman Nasional Bukit Duabelas (TNBD) dan Hutan Harapan (Gambar
1). Koordinat lokasi pengambilan sampel dari kedua lanskap dipetakan dengan menggunakan global positioning system (GPS). Terdapat 4 plot pengamatan di lahan hutan berukuran $50 \mathrm{~m}$ x 50 $\mathrm{m}$ dengan 3 subplot berupa kanopi pohon target. Jumlah subplot yang diamati dari kedua lanskap berjumlah 24 subplot. Pengambilan sampel serangga dilakukan pada dua musim, yaitu musim kering dari bulan Mei sampai Oktober 2013 dan musim hujan dari bulan November 2013 sampai Maret 2014.

\section{Pengambilan sampel serangga}

Pengambilan sampel dilakukan dengan menggunakan metode pengasapan (fogging). Pengasapan dimulai pada pagi hari sekitar pukul 06.00 waktu setempat dengan mengarahkan alat fogging ke arah kanopi yang lebih tinggi selama 20 menit. Larutan yang digunakan untuk pengasapan adalah insektisida berbahan aktif piretroid sebanyak $50 \mathrm{ml}$ yang telah dicampur dengan minyak putih sebanyak 4,5 liter. Sebanyak 16 wadah penampungan berbentuk kerucut yang terbuat dari bahan nilon berukuran $1 \mathrm{~m} \mathrm{x} 1 \mathrm{~m}$ dipasang pada bagian bawah kanopi pohon target (Gambar 2). Setiap wadah penampungan dipasang botol plastik pada bagian bawahnya yang telah berisi etanol 96\%, kemudian diberi label sesuai kode plot pengambilan sampel. Setelah dua jam pengasapan, serangga yang terjatuh dari

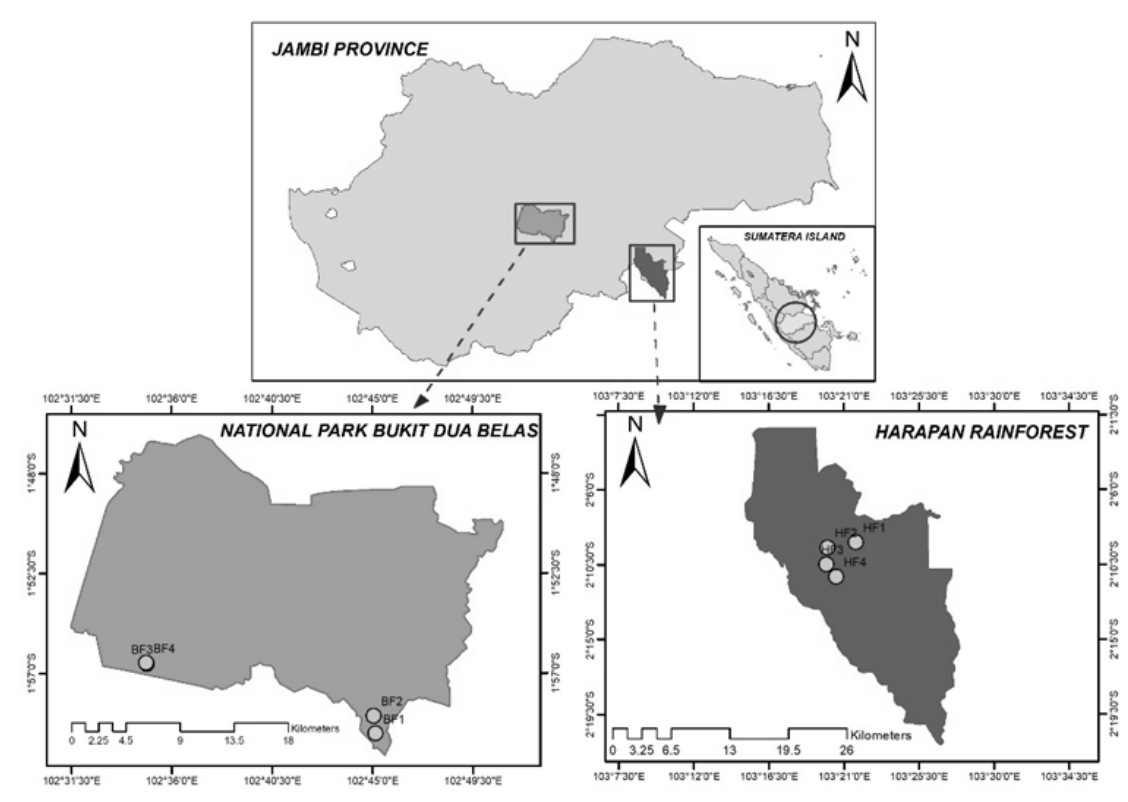

Legenda : $\bigcirc \quad$ Forest sample plot

Gambar 1. Peta lokasi penelitian di Provinsi Jambi. 
setiap pohon target tertampung dalam wadah penampungan kemudian dikumpulkan dan dibawa ke laboratorium untuk disortir dan diidentifikasi.

\section{Identifikasi kumbang elaterid}

Sampel serangga yang telah dikumpulkan disortir berdasarkan tingkat ordo, kemudian dipilih Ordo Coleoptera, selanjutnya dipilih Famili Elateridae (kumbang elaterid) untuk didentifikasi. Pemisahan spesimen kumbang elaterid dilakukan dengan membandingkan karakter morfologi dari masing-masing morfospesies. Proses identifikasi menggunakan beberapa buku dan jurnal kunci identifikasi, antara lain Dogger (1959), Stibick (1979), Calder (1996), Johnson (2002), Chakraborty \& Chakrabarti (2006), Lompe (2015), serta beberapa tambahan literatur dari berbagai sumber dan jurnal. Identifikasi kumbang elaterid telah melewati tahap verifikasi ulang dan pencocokkan dengan spesimen kumbang elaterid di Laboratorium Entomologi, LIPI, Cibinong.

\section{Analisis data}

Data hasil identifikasi ditabulasikan dalam bentuk pivot table pada program Microsoft Excel sehingga menjadi database. Kemudian data tersebut diolah menggunakan perangkat lunak $R$ statistic versi 3.6.1 dengan package vegan dan bipartite sehingga diperoleh nilai indeks keanekaragaman Shannon-Wienner $\left(\mathrm{H}^{\prime}\right)$, Simpson, dan Evenness (E). Pengaruh perbedaan lanskap terhadap keanekaragaman, kekayaan, dan kelimpahan kumbang elaterid dianalisis menggunakan uji analysis of variance (ANOVA) pada taraf nyata $5 \%$. Persentase kekayaan spesies kumbang elaterid diduga dengan menggunakan

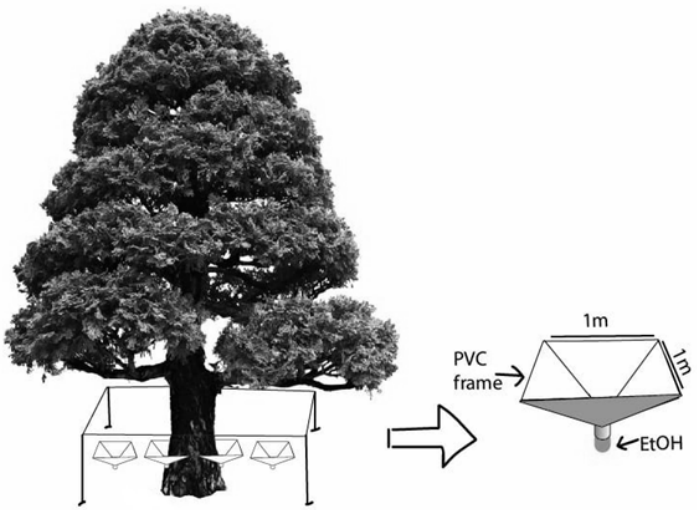

Gambar 2. Ilustrasi pemasangan wadah penampungan sampel. nilai abundance-based coverage estimator (ACE) yang diolah dari perangkat lunak Estimate $\mathrm{S}$ versi 9.1.0.

Uji lanjut untuk mengetahui pengaruh perbedaan lanskap hutan hujan tropis terhadap struktur komposisi kumbang elaterid menggunakan uji analysis of similarity (ANOSIM) pada taraf nyata 5\%. Uji ANOSIM di kedua lanskap dapat dibandingkan melalui analisis multidimentional scalling (MDS). Analisis MDS dapat digunakan untuk memberikan gambaran visual dari pola kedekatan berupa persamaan atau jarak di antara sekumpulan objek (Nazarreta 2017). Hasil analisis MDS dapat menghasilkan grafik nonmetric multidimensional scalling (NMDS) berupa gambaran visual dari perbedaan struktur komposisi spesies kumbang elaterid pada lanskap TNBD dan Hutan Harapan.

\section{HASIL}

\section{Keanekaragaman kumbang elaterid di dua lanskap hutan hujan tropis}

Kumbang elaterid yang ditemukan di kawasan hutan pada lanskap TNBD dan Hutan Harapan berjumlah 2.069 individu, terdiri atas 6 subfamili, 23 genus, dan 59 morfospesies (Tabel 1). Total kumbang elaterid yang diperoleh pada lanskap TNBD berjumlah 672 individu, terdiri atas 6 subfamili, 21 genus, dan 47 morfospesies. Sementara, pada lanskap Hutan Harapan berjumlah 1.397 individu, terdiri atas 6 subfamili, 18 genus, dan 40 morfospesies. Kekayaan spesies kumbang elaterid ditemukan lebih tinggi di lanskap TNBD,

Tabel 1. Kekayaan, kelimpahan, dan nilai indeks keanekaragaman kumbang elaterid pada lanskap TNBD dan Hutan Harapan

\begin{tabular}{lcc}
\hline $\begin{array}{l}\text { Indeks } \\
\text { keanekaragaman }\end{array}$ & TNBD & Hutan Harapan \\
\hline $\mathrm{S}$ & 47 & 40 \\
$\mathrm{H}$ & 2,34 & 1,40 \\
$\mathrm{E}$ & 0,60 & 0,38 \\
$\mathrm{~N}$ & 672 & 1.397 \\
$\mathrm{D}_{\mathrm{s}}$ & 0,80 & 0,60 \\
\hline
\end{tabular}

S: jumlah spesies; H: indeks Shannon-Wienner; E: indeks Evenness; N: jumlah individu; dan $\mathrm{D}_{\mathrm{s}}$ : indeks Simpson. 
namun kelimpahan individu kumbang elaterid lebih tinggi di lanskap Hutan Harapan. Hasil analisis ragam (ANOVA) menunjukkan bahwa perbedaan lanskap memengaruhi kelimpahan individu kumbang elaterid $\left(\mathrm{F}_{(1,6)}=8,2 ; \mathrm{P}=0,0287\right.$, $\mathrm{P}<0,05)$, namun tidak memengaruhi kekayaan spesies $\left(\mathrm{F}_{(1,6)}=0,475 ; \mathrm{P}=0,516, \mathrm{P}<0,05\right)$.

Hasil analisis indeks keanekaragaman (Tabel 1) menunjukkan bahwa nilai indeks ShannonWienner di lanskap TNBD $\left(\mathrm{H}^{\prime}=2,34\right)$ lebih tinggi dibandingkan dengan di lanskap Hutan Harapan $\left(\mathrm{H}^{\prime}\right.$ $=1,40)$. Nilai indeks Evenness juga menunjukkan hasil yang sama, nilai tertinggi terdapat di lanskap TNBD $(E=0,60)$ yang berarti tingkat kemerataan spesies berada dalam kategori sedang, sementara di lanskap Hutan Harapan $(\mathrm{E}=0,38)$ memiliki nilai indeks Evenness yang lebih rendah. Hasil indeks Simpson juga menunjukkan bahwa nilai indeks Simpson pada lanskap TNBD $(=0,80)$ lebih tinggi dibandingkan dengan di lanskap Hutan Harapan ( $=0,60$ ). Hal ini berarti, terdapat spesies kumbang elaterid yang mendominasi kawasan tersebut karena nilai indeks Simpson yang dihasilkan mendekati angka maksimal $(1,00)$.

\section{Kekayaan spesies kumbang elaterid di dua lanskap hutan hujan tropis}

Subfamili yang memiliki kekayaan spesies kumbang elaterid tertinggi di antaranya adalah Subfamili Elaterinae (30 morfospesies), kemudian diikuti oleh Agrypninae (18 morfospesies), Cardiophorinae (4 morfospesies), Negastriinae (3 morfospesies), Dendrometrinae (2 morfospesies), dan Melanotinae (2 morfospesies). Hasil penelitian menunjukkan bahwa sebesar 85,30\% spesies kumbang elaterid berhasil diperoleh melalui metode pengasapan (fogging) yang dilakukan di kedua lanskap hutan hujan tropis dengan persentase nilai ACE masing-masing sebesar 79,41\% di lanskap TNBD dan 72,20\% di lanskap Hutan Harapan. Nilai tersebut merupakan persentase keberhasilan spesies kumbang elaterid yang diperoleh dari total keseluruhan yang ada di lahan.

Berdasarkan data pada Tabel 2, terdapat spesies kumbang elaterid yang ditemukan di kedua lanskap, yaitu Adelocera sp.01, Agraeus sp.05, Ampedus sp.04, Cardiophorus sp.01, Esthesopus sp.01, dan lain-lain (Gambar 3). Selain

Tabel 2. Morfospesies kumbang elaterid presence-absence pada lanskap TNBD dan Hutan Harapan

\begin{tabular}{|c|c|c|}
\hline $\begin{array}{l}\text { Subfamili } \\
\quad \text { Morfospesies }\end{array}$ & TNBD & Hutan Harapan \\
\hline \multicolumn{3}{|l|}{ Agrypninae } \\
\hline Adelocera sp.01 & + & + \\
\hline Adelocera sp.02 & + & + \\
\hline Adelocera sp.03 & + & + \\
\hline Adelocera sp.04 & + & + \\
\hline Agraeus candezei & & + \\
\hline Agraeus sp.01 & & + \\
\hline Agraeus sp.03 & & + \\
\hline Agraeus sp.04 & & + \\
\hline Agraeus sp.05 & + & + \\
\hline Agraeus sp.06 & + & + \\
\hline Agrypnus sp.01 & & + \\
\hline Agrypnus sp.02 & + & \\
\hline Alaus sp.01 & & + \\
\hline Dilobitarsus pendleburyi & & + \\
\hline Heteroderes sp.01 & + & + \\
\hline Heteroderes sp.02 & + & + \\
\hline Heteroderes sp.03 & + & + \\
\hline Heteroderes sp.04 & + & \\
\hline
\end{tabular}


Tabel 2. Lanjutan

\begin{tabular}{|c|c|c|}
\hline $\begin{array}{l}\text { Subfamili } \\
\text { Morfospesies }\end{array}$ & TNBD & Hutan Harapan \\
\hline Cardiophorinae & + & + \\
\hline Cardiophorus fasciatus Cand. & + & \\
\hline Cardiophorus sp.01 & + & + \\
\hline Esthesopus sp.01 & + & + \\
\hline Esthesopus sp.02 & + & \\
\hline Dendrometrinae & + & + \\
\hline Hypnoidus sp.01 & + & + \\
\hline Senodonia quadricollis & + & \\
\hline Elaterinae & + & + \\
\hline Ampedus sp.01 & + & \\
\hline Ampedus sp.02 & + & \\
\hline Ampedus sp.03 & + & \\
\hline Ampedus sp.04 & + & + \\
\hline Ampedus sp.05 & & + \\
\hline Dalopius sp.01 & + & \\
\hline Gamepenthes decemnotatus & + & \\
\hline Gamepenthes sp.01 & + & \\
\hline Gamepenthes sp.02 & + & + \\
\hline Gamepenthes sp.03 & + & + \\
\hline Glyphonyx sp.01 & + & + \\
\hline Glyphonyx sp.02 & + & + \\
\hline Glyphonyx sp.03 & + & \\
\hline Glyphonyx sp.04 & & + \\
\hline Glyphonyx zonatus & + & + \\
\hline Megapenthes sp.01 & + & + \\
\hline Megapenthes sp.02 & + & \\
\hline Melanoxanthus fractus Cand. & + & + \\
\hline Melanoxanthus sp.01 & + & + \\
\hline Melanoxanthus sp.02 & + & + \\
\hline Melanoxanthus sp.05 & & + \\
\hline Melanoxanthus sp.07 & + & + \\
\hline Mulsanteus illotipes & + & \\
\hline Mulsanteus sp.01 & + & \\
\hline Pachyderes sp.01 & + & \\
\hline Simodactylus sp.01 & + & \\
\hline Xanthopenthes sp.01 & + & + \\
\hline Xanthopenthes sp.02 & + & + \\
\hline Xanthopenthes sp.03 & + & \\
\hline Xanthopenthes sp.04 & & + \\
\hline Melanotinae & + & + \\
\hline Melanotus sp.01 & + & \\
\hline Melanotus sp.02 & + & + \\
\hline
\end{tabular}


Tabel 2. Lanjutan

\begin{tabular}{lcc}
\hline $\begin{array}{l}\text { Subfamili } \\
\text { Morfospesies }\end{array}$ & TNBD & Hutan Harapan \\
\hline Negastriinae & + & + \\
Quasimus sp.01 & + & + \\
Zorochros sp.01 & & + \\
Zorochros sp.02 & + & + \\
\hline
\end{tabular}

+: menunjukkan keberadaan kumbang klik pada lanskap TNBD dan Hutan Harapan.

itu, juga terdapat spesies kumbang elaterid yang hanya ditemukan di masing-masing lanskap, yaitu pada lanskap TNBD antara lain Agrypnus sp.02, Heteroderes sp.04, Cardiophorus fasciatus Cand., Esthesopus sp.02, Senodonia quadricollis, dan lain-lain. Sementara, spesies kumbang elaterid yang hanya ditemukan pada lanskap Hutan Harapan, antara lain Agraeus candezei, Agraeus sp.01, Agrypnus sp.01, Alaus sp.01, Dilobitarsus pendleburyi, dan lain-lain.

Kumbang elaterid yang ditemukan di kedua lanskap diduga termasuk dalam kategori spesies generalis, sedangkan kumbang elaterid yang hanya ditemukan pada salah satu lanskap diduga termasuk dalam kategori spesies unik. Spesies kumbang elaterid yang terdiri atas 1 individu merupakan spesies singleton sehingga dapat dikategorikan sebagai spesies langka (rare species) diantaranya adalah Agraeus candezei, Alaus sp.01, Dilobitarsus pendleburyi, Senodonia quadricollis, Pachyderes sp.01 dan lain-lain (Gambar 4).

\section{Perbedaan komposisi kumbang elaterid pada lanskap TNBD dan Hutan Harapan}

Analisis komposisi dan keanekaragaman kumbang elaterid terhadap pengaruh perbedaan musim tidak ditampilkan sebagai hasil penelitian sehingga data kedua musim diabaikan atau digabung dalam data lanskap. Akan tetapi, dari hasil analisis menunjukkan bahwa perbedaan musim memengaruhi komposisi spesies $(\mathrm{R}=0,2791 ; \mathrm{P}=$ $0,005, \mathrm{P}<0,05)$ dan kelimpahan $\left(\mathrm{F}_{(3.12)}=7,487 ; \mathrm{P}\right.$ $=0,00438, \mathrm{P}<0,05)$, namun tidak memengaruhi kekayaan spesies kumbang elaterid $\left(\mathrm{F}_{(3.12)}=0,858\right.$; $\mathrm{P}=0,489, \mathrm{P}<0,05)$. Berdasarkan hasil analisis MDS menunjukkan bahwa perbedaan lanskap memengaruhi komposisi morfospesies kumbang elaterid $(\mathrm{R}=0,5312 ; \mathrm{P}=0,023, \mathrm{P}<0,05)($ Gambar 5).

\section{PEMBAHASAN}

Nilai indeks keanekaragaman dipengaruhi berbagai faktor, di antaranya sumber makanan tersedia, kemampuan berkembang biak serangga (Jumar 2000), suhu, dan kelembaban udara (Borror 1996). Sementara itu, keanekaragaman dan komposisi kumbang elaterid pada kawasan hutan dipengaruhi oleh komposisi vegetasi, keanekaragaman struktur tegakan, dan jumlah kayu lapuk (Thomas 2007). Taman Nasional Bukit Duabelas (TNBD) menyimpan kekayaan spesies kumbang elaterid lebih tinggi, akan tetapi berdasarkan kelimpahan, Hutan Harapan memiliki jumlah individu kumbang elaterid lebih tinggi. Perbedaan lanskap TNBD dan Hutan Harapan memengaruhi kelimpahan individu dan komposisi kumbang elaterid, akan tetapi tidak memengaruhi kekayaan spesies di dalamnya. Kekayaan spesies kumbang elaterid tidak berbeda nyata dapat disebabkan oleh kondisi habitat dari kedua lanskap yang merupakan kawasan hutan hujan tropis dataran rendah di wilayah Jambi sehingga kedua kawasan ini diduga memiliki kesamaan jenis spesies kumbang elaterid. Akan tetapi, berkaitan dengan kelimpahan dan komposisi kumbang elaterid yang berbeda nyata di kedua lanskap, diduga dipengaruhi oleh struktur dan fungsi lanskap yang berbeda.

Kawasan hutan di TNBD terdiri atas hutan primer yang masih terjaga. Sementara itu, kawasan hutan di Hutan Harapan merupakan kawasan yang sebelumnya difungsikan sebagai hutan produksi yang saat ini telah berubah menjadi areal restorasi ekosistem. Kawasan Hutan Harapan merupakan hutan sekunder yang pernah mengalami peristiwa pembakaran yang disebabkan oleh faktor alam serta akibat dari konflik manusia (REDD+ 

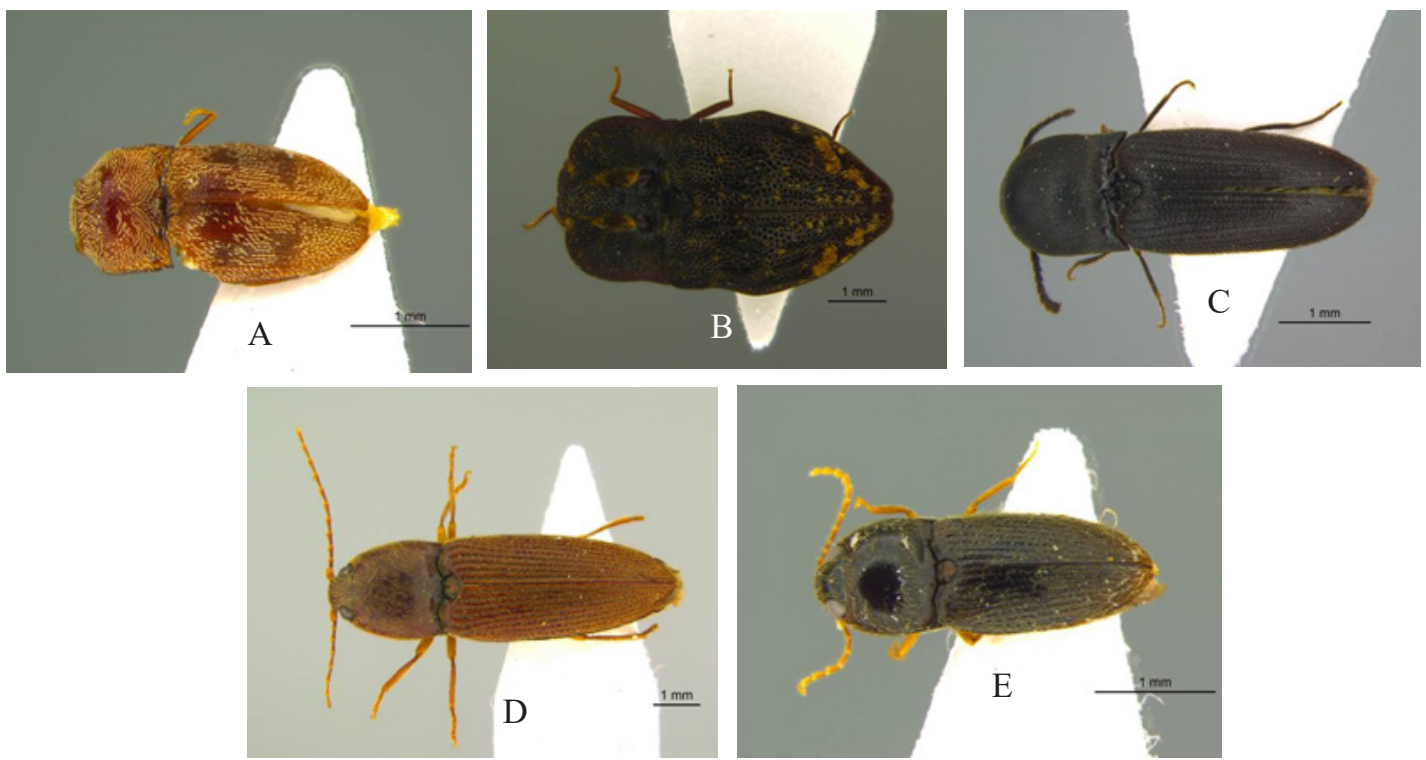

Gambar 3. Morfospesies kumbang elaterid yang ditemukan pada lanskap TNBD dan Hutan Harapan. A: Adelocera sp.01; B: Agraeus sp.05; C: Ampedus sp.04; D: Cardiophorus sp.01; E: Esthesopus sp.01.
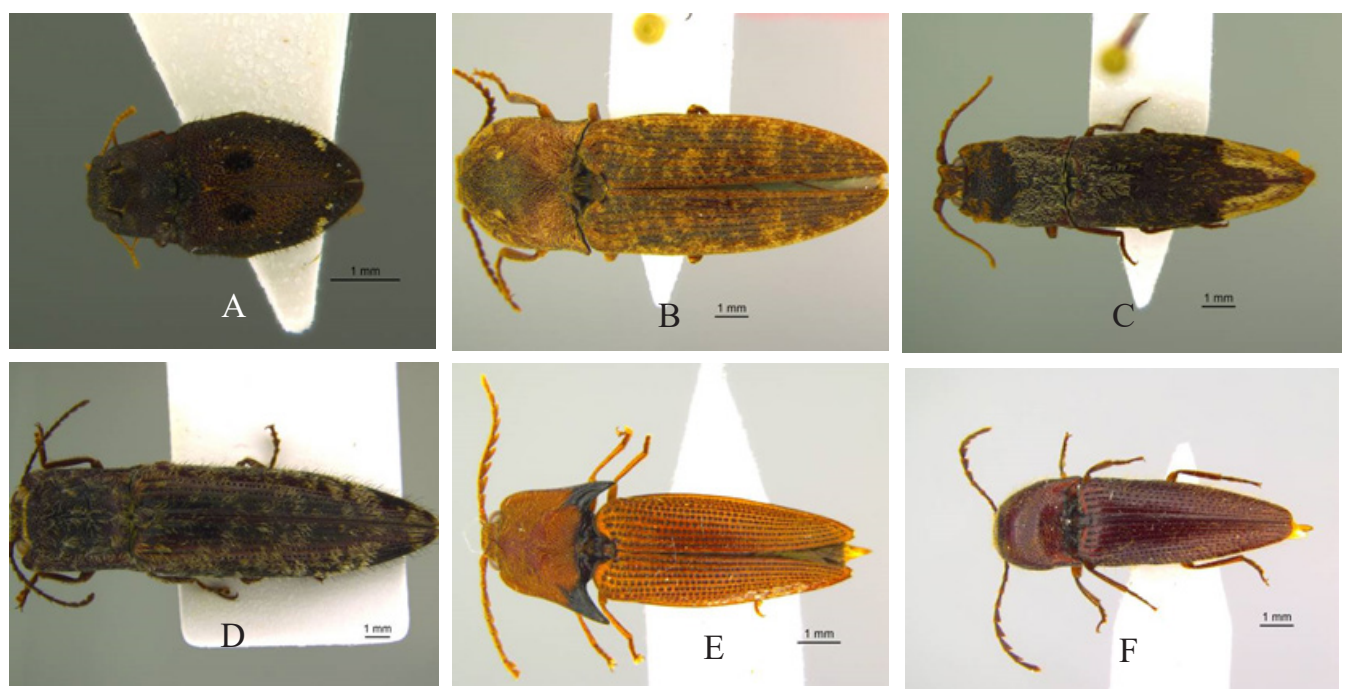

Gambar 4. Morfospesies kumbang elaterid yang bersifat langka dan unik. A: Agraeus candezei; B: Alaus sp.01; C: Dilobitarsus pendleburyi; D: Senodonia quadricollis; E: Pachyderes sp.01; F: Melanotus sp.01.

Indonesia 2016). Dharmawan et al. (2005) menyatakan bahwa keanekaragaman suatu spesies cenderung akan rendah pada ekosistem yang secara fisik terkendali atau mendapatkan tekanan lingkungan, berbeda dengan keanekaragaman pada ekosistem yang masih alami. Oleh karena itu, diduga hal inilah yang menyebabkan adanya perbedaan kelimpahan dan komposisi kumbang elaterid di kedua lanskap.

Thomas (2007) melaporkan bahwa keanekaragaman kumbang elaterid meningkat pada struktur tegakan tinggi dengan berbagai jenis vegetasi, serta terdapat perbedaan komposisi spesies di antara tegakan yang diamati. Sesuai dengan hasil penelitian menunjukkan bahwa jumlah spesies kumbang elaterid yang ditemukan di kawasan hutan pada lanskap TNBD lebih tinggi dibandingkan dengan di Hutan Harapan, serta komposisi spesies kumbang elaterid di kedua lanskap tersebut berbeda. Hal ini dapat disebabkan oleh kondisi hutan pada lanskap TNBD memiliki kelimpahan dan keanekaragaman vegetasi yang tinggi dan didominasi pepohonan yang lebih tinggi (Taman Nasional Bukit Duabelas 2017) dibandingkan dengan di lanskap Hutan Harapan. Kumbang elaterid dewasa (imago) akan 


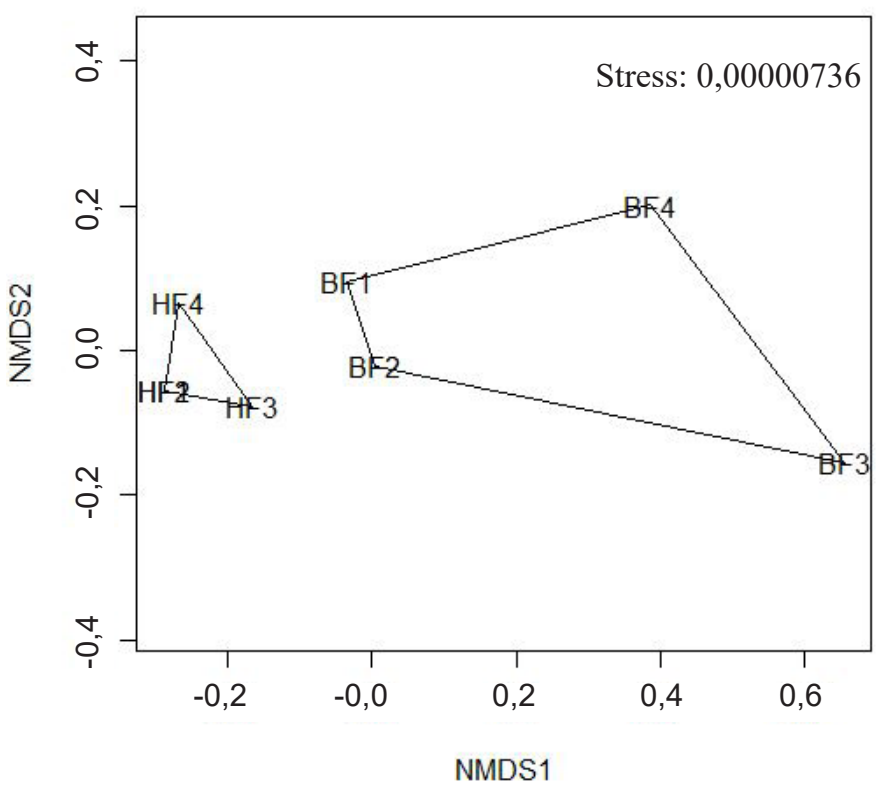

Gambar 5. Grafik NMDS komposisi spesies kumbang elaterid di kawasan hutan pada lanskap TNBD dan Hutan Harapan. BF: hutan di Taman Nasional Bukit Duabelas; HF: hutan di Hutan Harapan.

menempati suatu kanopi pohon untuk mencari makanan karena beberapa spesies memakan kutukutuan atau herbivora lain, dedaunan, nektar ataupun serbuk sari (Morris 1951; Yano et al. 1984; Johnson 2002).

Jumlah spesies dan individu kumbang elaterid yang diperoleh dalam penelitian ini tiga kali lebih banyak dibandingkan dengan hasil penelitian Mulerčikas et al. (2012) yang memperoleh 687 individu kumbang elaterid, terdiri atas 13 spesies dan 10 genus di wilayah Lithuania Selatan, Eropa. Hal ini diduga karena kondisi habitat dan lingkungan, serta metode pengambilan sampel yang berbeda dari kedua penelitian ini. Penelitian Mulerčikas et al. (2012) menggunakan perangkap pitfall, sedangkan penelitian ini menggunakan metode pengasapan (fogging). Hasil yang lebih tinggi pada penelitian ini diduga karena habitat yang diamati merupakan kawasan hutan hujan tropis yang menyimpan banyak kekayaan dan keanekaragaman spesies, khususnya serangga. Selain itu, metode pengambilan sampel dengan cara fogging lebih efektif dalam mengumpulkan serangga arboreal karena kumbang elaterid tidak hanya bersifat terestrial, akan tetapi juga banyak spesies yang bersifat arboreal khususnya pada fase dewasa (imago).

Kumbang elaterid yang memiliki kelimpahan tertinggi berasal dari subfamili Agrypninae, sedangkan untuk kekayaan tertinggi berasal dari subfamili Elaterinae. Hasil ini didukung oleh laporan Calder (1998) yang menyatakan bahwa Subfamili Agrypninae memiliki kelimpahan individu kumbang elaterid terbesar dalam Famili Elateridae yang terdiri atas 115 genus dengan 2.300 spesies tersebar di seluruh dunia. Sementara itu, Subfamili Elaterinae termasuk dalam kelompok subfamili dengan kekayaan spesies terbesar dalam Famili Elateridae. Stibick (1979) melaporkan bahwa sekitar lebih dari 180 genus dengan 800 spesies kumbang elaterid dari Subfamili Elaterinae tersebar di seluruh dunia. Kumbang elaterid yang mendominasi di kedua lanskap berasal dari Genus Adelocera dengan morfospesies Adelocera sp.01. von Hayek (1979) menyatakan bahwa Genus Adelocera merupakan salah satu genus dengan kelimpahan dan kekayaan spesies tertinggi setelah Genus Agrypnus dalam Subfamili Agrypninae.

Chakraborty \& Chakrabarti (2006) melaporkan beberapa jenis spesies kumbang elaterid yang berperan sebagai predator dan hama. Spesies kumbang elaterid dari genus Agrypnus, Adelocera, Melanotus, dan Heteroderes berperan sebagai predator pada fase larva. Spesies dari genus Agrypnus dan Melanotus pada fase larva hidup di dalam kayu yang membusuk. Sementara itu, beberapa spesies dari Genus Adelocera dan Heteroderes hidup di tanah dan memangsa serangga lain yang juga hidup di tanah khususnya larva kumbang Scarab, akan tetapi pada fase imago 
dapat ditemukan di pepohonan. Kumbang elaterid dari genus Calais (sinonim: Paracalais) juga diketahui berperan sebagai predator untuk larva dan pupa kumbang Cerambycid. Spesies tertentu dari genus Cardiophorus dilaporkan menyerang pepohonan, seperti bambu (Cephalostachyum pergracile) dan pinus (Casuarina equisetifolia). van Herk \& Vernon (2014) juga melaporkan, spesies dari genus Hypnoidus (Subfamili: Dendrometrinae) Dalopius (Subfamili: Elaterinae) menjadi hama penting pada pertanaman serealia, seperti gandum di wilayah Alberta, Saskatchewan, dan Manitoba, Canada.

Kumbang elaterid yang ditemukan pada penelitian ini terdiri atas kumbang elaterid dengan kategori spesies general dan spesies khusus. Kumbang elaterid yang bersifat general diduga dapat beradaptasi pada kondisi habitat di kedua lanskap, sedangkan kumbang elaterid khusus hanya mampu beradaptasi pada salah satu lanskap tertentu. Menurut Prasetyo (2017), spesies generalis dapat memanfaatkan lebih banyak sumberdaya, mempunyai daya adaptasi tinggi, dan tidak terisolasi dibandingkan dengan spesies spesialis (spesies khusus) yang tidak dapat beradaptasi pada berbagai tempat karena keterbatasan sumberdaya.

Beberapa spesies kumbang elaterid yang ditemukan memiliki karakter unik, antara lain morfospesies Alaus sp.01 dengan ciri khas pola mata palsu pada bagian pronotum (Woodruff 2018), genus Pachyderes dengan ciri khas pronotum yang melebar dan meruncing pada bagian ujung, serta genus Melanotus dengan karakter kuku berbentuk seperti sisir (Chakraborty \& Chakrabarti 2006). Spesies kumbang elaterid dari Subfamili Negastriinae (Quasimus dan Zorochros) memiliki ukuran lebih kecil dibandingkan dengan spesies kumbang elaterid dari subfamili lainnya dengan kisaran panjang tubuh hanya mencapai kurang dari $2 \mathrm{~mm}$ (Stibick 1990).

Keanekaragaman vegetasi menjadi faktor penting dalam keberlangsungan hidup kumbang elaterid karena berperan penting dalam penyediaan sumber makanan dan sebagai habitat atau tempat hidup. Erwin (1990) menyatakan, semakin banyak kanopi yang terdapat pada suatu habitat maka akan semakin tinggi keanekaragaman spesies di habitat tersebut. Berdasarkan hasil penelitian, dapat diketahui bahwa data identifikasi kumbang elaterid yang diperoleh dapat menjadi data awal yang memberikan informasi baru terkait keanekaragaman kumbang elaterid, khususnya di wilayah Jambi. Hasil analisis yang menunjukkan adanya pengaruh komposisi dan kelimpahan kumbang elaterid terhadap perbedaan lanskap hutan dapat menjadi acuan dasar dalam upaya menjaga kelestarian kawasan hutan.

\section{KESIMPULAN}

Keanekaragaman dan kekayaan spesies kumbang elaterid pada lanskap TNBD lebih tinggi dibandingkan dengan di lanskap Hutan Harapan, akan tetapi kelimpahan individu kumbang elaterid lebih tinggi pada lanskap Hutan Harapan. Jumlah kumbang elaterid yang diperoleh pada lanskap TNBD sebanyak 672 individu, terdiri atas 6 subfamili, 21 genus, dan 47 morfospesies. Sementara itu, pada lanskap Hutan Harapan diperoleh sebanyak 1.397 individu, terdiri atas 6 subfamili, 18 genus, dan 40 morfospesies. Perbedaan lanskap memengaruhi komposisi dan kelimpahan individu kumbang elaterid, akan tetapi tidak memengaruhi kekayaan spesies di dalamnya. Kumbang elaterid dengan kelimpahan tertinggi berasal dari Subfamili Agrypninae, sedangkan kekayaan tertinggi berasal dari Subfamili Elaterinae. Morfospesies kumbang Elateridae yang mendominasi di kedua lanskap tersebut berasal dari genus Adelocera, yaitu Adelocera sp.01.

\section{UCAPAN TERIMA KASIH}

Penulis menyampaikan ucapan terima kasih kepada CRC-990/EFForTS, juga terkhusus kepada Prof. Stefan Scheu dan Dr. Jochen Drescher yang telah membantu berjalannya penelitian grup Z02. CRC990-EFForTS (Ecological and Socio-economic Functions of Tropical Lowland Rainforest Transformation Systems) merupakan proyek kerja sama antara beberapa kampus di Indonesia, yaitu Institut Pertanian Bogor, Universitas Jambi, dan Universitas Tadulako dengan Universitas Göttingen, Jerman. Penulis juga menyampaikan ucapan terima kasih 
kepada Lembaga Ilmu Pengetahuan Indonesia (LIPI) khususnya tim peneliti di Laboratorium Entomologi yang telah membantu dalam proses identifikasi kumbang elaterid.

\section{DAFTAR PUSTAKA}

Borror DJ, Triplehorn CA, Johnson NF. 1996. Pengenalan Pelajaran Serangga. Partosoedjono $\mathrm{S}$, Brotowidjoyo MD, penerjemah. Terjemahan dari: Study of Insect. Edisi ke-6. Yogyakarta: Gadjah Mada University Press.

Bouchard P, Smith ABT, Douglas H, Gimmel ML, Brunke AJ, Kand K. 2017. Biodiversity of Coleoptera. Insect Biodiversity: Science and Society 1:337-417. doi: https://doi. org/10.1002/9781118945568.ch11.

Calder AA. 1996. Elaterid Beetles: Genera of the Australian Elateridae (Coleoptera). Melbourne: CSIRO Publishing.

Calder AA. 1998. Coleoptera: Elateroidea. Di dalam: Wells A. (Ed.) Zoological Catalogue of Australia 29:38-97. Melbourne: CSIRO Publishing.

Chakraborty P, Chakrabarti S. 2006. A contribution to the fauna of Elaterid-Beetles (Coleoptera: Elateroidea : Elateridae) of West Bengal. Records of the Zoological Survey of India 254:1-220.

[DEPHUT] Departemen Kehutanan. 2005. Rencana Pengelolaan Taman Nasional Bukit Duabelas. Bogor: Direktorat Jenderal PHKA.

Dharmawan A, Tuarita H, Ibrohim, Suwono H, Susanto P. 2005. Ekologi Hewan. Malang: UM Press.

Dogger JR. 1959. The elateridae of Wisconsin: a list of the species found in wisconsin and keys to the identification of genera of adults and larvae. Wisconsin Academy of Sciences, Arts, and Letters 48:103-120.

Erwin TL. 1990. Canopy arthropod biodiversity: a chronology of sampling techniques and results. Revista Peruana de Entomologia 32:71-77.

[FWI] Forest Watch Indonesia. 2014. Potret Keadaan Hutan Indonesia Tahun 2009-2013. Bogor: Forest Watch Indonesia.

Grove SJ. 2002. Saproxylic insect ecology and the sustainable management of forests. Annual Review of Ecology, Evolution, and Systematics 33:1-23. doi: https://doi.org/10.1146/annurev. ecolsys.33.010802.150507.

Harrison RD, Swinfield T. 2015. Restoration of logged humid tropical forests: an experimental programme at Harapan Rainforest, Indonesia. Tropical Conservation Science 8:4-16. doi: https://doi.org/10.1177/194008291500800103.

Jaboury G, Sheil D. 2010. Tropical rain forest ecology, diversity, and conservation. New York: Oxford University Press.

Janzen DH. 1987. Insect diversity of a Costa Rica, dry forest: why keep it and how. Botanical Journal of the Linnean Society 30:343-356. doi: https:// doi.org/10.1111/j.1095-8312.1987.tb00307.x.

Johnson PJ. 2002. Family 58. Elateridae Leach 1815. Di dalam: Arnett RH Jr., Thomas MC, Skelley PE, Frank JH (Eds.), American Beetles Vol. 2: Polyphaga Scarabaeoidea through Curculionoidea. hlm. 160-173. Gainesville: CRC Press.

Johnson PJ, Chaboo CS. 2015. Beetles (Coleoptera) of Peru: a survey of the families. Elateridae Leach, 1815. Journal of The Kansas Entomological Society 88:269-272. doi: https://doi.org/10.2317/ kent-88-02-269-272.1.

Jumar. 2000. Entomologi Pertanian. Jakarta: Rineka Cipta.

Kahono S, Amir M. 2003. Serangga Taman Nasional Gunung Halimun Jawa Bagian Barat. Bogor: Biodiversity Conservation Project in IndonesiaJICA.

Kundrata RM, Bocáková, Bocák L. 2014. The comprehensive phylogeny of the superfamily Elateroidea (Coleoptera: Elateriformia). Molecular Phylogenetics and Evolution 76:162-171. doi: https://doi.org/10.1016/j.ympev.2014.03.012.

Lompe A. 2015. Family Elateridae: Key to the British Elateridae. Hackton M, translator and adapter. Translated from: Käfer Europas: Elateridae. Tersedia pada: http://www.coleo-net.de/coleo/ texte/elateridae.htm [diakses 3 Mei 2017].

Luterek D. 1966. Observations on the larvae of some species of elaterid beetles (Coleoptera: Elateridae) feeding on mushrooms. Polish Journal of Entomology 3:341-345.

Morris RF. 1951. The larval elateridae of eastern spruce forests and their role in the natural control of Gilpinia hercyniae (Htg.) (Hymenoptera: Diprionidae). The Canadian Entomologist 83: 133-147. doi:https://doi.org/10.4039/Ent83133-6.

Mulerčikas P, Tamutis V, Kazlauskaite S. 2012. Species composition and abundance of elaterid-beetles (Coleoptera: Elateridae) in agrobiocenozes in Southern Lithuania. Polish Journal of Environmental Studies 21:425-433.

Mwansat GS, Turshak LG, Okolie M O. 2015. Insects an important delicacy for birds: expanding our 
knowledge of insect food ecology of birds in the tropics. Journal of International Scientific Publications 9:434-441.

Nazarreta R. 2017. Keanekaragaman dan Identifikasi Semut Arboreal di Lanskap Hutan Harapan dan Taman Nasional Bukit Duabelas, Jambi. Thesis. Bogor: Institut Pertanian Bogor.

Paknia O, Rajaei Sh H, Koch A. 2015. Lack of well-maintained natural history collections and taxonomists in megadiverse developing countries hampers global biodiversity exploration. Organisms Diversity and Evolution 15:619-629. doi: https://doi.org/10.1007/s13127-015-0202-1.

Peter CI, Johnson SD. 2005. Anther cap retention prevents self-pollination by elaterid beetles in the South African orchid Eulophia foliosa. Annals of Botany 97:345-355. doi: https://doi. org/10.1093/aob/mcj041.

REDD+ Indonesia. 2016. Pelajaran Resolusi Konflik di Hutan Harapan. Buletin REDD+ Indonesia. Jakarta: Kementerian Lingkungan Hidup dan Kehutanan bekerja sama dengan Program REDD+ UND.

Portal Informasi Indonesia. 2018. Anugerah dari hutan Indonesia. Tersedia pada: https://indonesia. go.id/ragam/keanekaragaman-hayati/ekonomi/ anugerah-dari-hutan-indonesia [diakses 18 Juni 2019].

Prasetyo LB. 2017. Pendekatan Ekologi Lanskap untuk Konservasi Biodiversitas. Bogor: Fakultas Kehutanan, Institut Pertanian Bogor

Schowalter TD. 2011. Insect Ecology: An Ecosystem Approach $3^{\text {th }}$ Edition. Oxford: Elseve.

Stibick JNL. 1990. North American Negastriinae (Coleoptera, Elateridae): the Negastriinae of the Eastern United States and adjacent Canada. Insecta Mundi 4:99-131.

Stibick JNL. 1979. Classification of the Elateridae (Coleoptera): Relationships and classification of the subfamilies and tribes. Journal of Pasific Insects 20:145-186.
Taman Nasional Bukit Duabelas. 2017. Keanekaragaman hayati. Tersedia pada: http://www. tnbukitduabelas.id/profile/keanekaragamanhayati [diakses 27 Juni 2019].

Thomas SL. 2007. Effects of forest management on elaterid beetle (Coleoptera: Elateridae) assemblages in the acadian forest of Maine. Electronic Theses. Tersedia pada: http:// digitalcommons.library.umainee.edu/etd [diakses 13 Juni 2017].

van Herk WG, Vernon RS. 2014. Elaterid beetles and wireworms (Coleoptera: Elateridae) of Alberta, Saskatchewan, and Manitoba. Di dalam: Giberson D, Cárcamo HA (Eds.), Arthropods of Canadian Grasslands Vol. 4: Biodiversity and Systematics Part 2. Edited by Biological Survey of Canada. pp. 87-117. Ottawa: Biological Survey of Canada.

von Hayek CMF. 1979. Additions and corrections to a reclassification of the subfamily Agrypninae (Coleoptera: Elateridae). Bulletin of the British Museum (Natural History) Entomology 38:183261.

Warriner MD, Nebeker TE, Leininger TD, Meadows JS. 2002. The Effects of Thinning on Beetles (Coleoptera: Carabidae, Cerambycidae) in Bottomland Hardwood Forests. Mississippi: Departement of Entomology and Plant Pathology, Mississippi State University.

Wolters V. 1989. The influence of omnivorous elaterid larvae on the microbial carbon cycle in different forest soils. Oecologia 80:405-413. doi: https://doi.org/10.1007/BF00379044.

Woodruff RE. 2018. Click beetles, Alaus spp. (Insecta: Coleoptera: Elateridae). EDIS 4:1-4.

Yano K, Tsuchiya K, Hamasaki S. 1984. Aphidfeeding by adult Elaterid beetles (Coleoptera: Elateridae). Entomological Society of Japan 52:441-444. 